\title{
SMAD5 wt Allele
}

National Cancer Institute

\section{Source}

National Cancer Institute. SMAD5 wt Allele. NCI Thesaurus. Code C118586.

Human SMAD5 wild-type allele is located in the vicinity of $5 q 31$ and is approximately $56 \mathrm{~kb}$ in length. This allele, which encodes mothers against decapentaplegic homolog 5 protein, plays a role in the regulation of gene expression. 